\title{
PROFESSIONALIZATION OF POLITICAL CAMPAIGNS: ROADMAP FOR THE ANALYSIS ${ }^{1}$
}

\author{
Daniela Ostrá2
}

\begin{abstract}
Political parties in developed democracies have undergone deep inner transformation processes brought about by changes in voting behaviour of their electorates, fragmentation of media landscape, and technological revolution. Such changes have caused that the topic of political party transformation has become a central focus of current political science research. However, only a few works have addressed specific aspects of these far-reaching transformations, that is the process of modernisation and professionalization of political campaigns. Specifically, the recent research on professionalization of electoral campaigns has focused primarily on measurement of the index of professionalization, which is suitable for comparative research. Yet deep understanding of the process itself has been still absent, and therefore, this research paper aspires to cover this gap. Main goal of this paper is to offer a roadmap for analysis of professionalization of electoral campaigns with focus on qualitative studies. It represents a causal mechanism of professionalization of electoral campaigns, including the identification of internal and external factors and possible framework conditions that contribute to it (i.e. professionalization), through the process of tracing method (i.e. the causal mechanism is built on the basis of the process tracing method). Here, external factors are defined as environmental conditions, which include declining voter turnout, declining party identification, increasing electoral volatility, and declining interest in political party membership. Although their effect is considered a longterm one, the causal mechanism assumes their influence on the triggering of other processes: external shock (electoral win or loss) and internal shock (change of leader). In the next part of the causal mechanism, subsequent internal processes are expected in the form of changes to the primary goal and organizational structure of parties. Unlike previously published works on this topic, this paper suggests that not only the specific internal and external factors or amount of invested financial resources affect the degree of professionalization, but also the party's market orientation and the level of its internal discipline.
\end{abstract}

KEY WORDS: Political campaigns, Professionalization, Process tracing, Party politics.

${ }^{1}$ This study was conducted with the support of MŠMT granted by Palacky University in Olomouc. (IGA_FF_2019_034)

${ }^{2}$ Faculty of Arts, Palacky University in Olomouc, Křížkovského 12, Olomouc, Czech Republic. E-mail: daniela.vasatkova@gmail.com. ORCID ID: https://orcid.org/0000-0002-0778-3242. 


\section{INTRODUCTION}

Research on the professionalization of political campaigns is conducted upon a general consensus among the authors on the completely vital role of hired experts in the field of data processing, PR and media. Various theoretical and empirical studies define variables that can contribute to the professionalization of campaigns. Gibson and Römmele (2009) in their study introduced a causal model, which is based on the assumption that the research of professionalization requires consider specific party variables, not just changes undergone at the system level. Subsequently, their work was followed by Strömbäck (2009) and Tenscher with Mykkänen (2014). Approach of these authors is based on the theory of party change by Harmel and Janda (1994), who argue that changes in behaviour of political parties are a combination of external shocks caused by the environment and internal shocks that take place within political parties and can take a wide range of forms. Although these are studies of an earlier date of publication, we feel the need to develop them with the recent knowledge. So far, in the research of the professionalization of campaigns, understanding of the processes that take place within political parties due to external and internal factors is absent, altogether with a systematic acknowledgement of the factors affecting the degree of professionalization. In consequence, this paper inheres two primary goals. The first is to systematize the existing knowledge on the research of professionalization of campaigns and on the basis of already published empirical and theoretical studies to identify the factors that can contribute to professionalization, including the way of their operationalization. The second subsequent goal is to uncover the processes that take place within political parties in response to external and internal impulses and to introduce the first proposal of a comprehensive causal mechanism for the professionalization of electoral campaigns.

Both primary goals are addressed in the following research questions:

- What factors contribute to the professionalization of campaigns?

- What processes occur in response to external and internal impulses within political parties?

Answering the questions determined above enable presentation of a comprehensive causal mechanism for professionalization of campaigns, that is based on the logic of the process-tracing method and is exceptionally proper for qualitative studies. The process-tracing method was chosen deliberately, as it represents a specific approach to one case studies or 
studies with a small number of N. Primary focus of this method is therefore on causal conditions, settings and mechanisms that allow the emergence of certain outputs (Blatter, Haverland, 2014). In a process-tracing, causality is perceived through mechanisms, i.e. some systems that change causal forces from causes to consequences.

The hypothetic causal mechanism presented herein defines not only environmental factors that affect the position of the parties in the political market. Nevertheless, it also specifies the nature of the internal and external shocks, to which political parties are exposed and the processes that arise from their interaction. Subsequently, paper also lists the conditions that can affect the resulting degree of professionalization of campaigns. Compared to the Gibson and Römmele or Tenscher and Mykkänen, a strong influence of party discipline and market orientation of the party on the final form of professionalization of campaigns is assumed.

With the aim offulfilling the goals above, the introductory part of the article offers conceptualisation and definition of the concept of professionalization, including an introduction and comparison of all previously published methods for measuring the degree of professionalization of authors Gibson, Römmele (2009), Strömbäck (2009), Tenscher and Mykkänen (2014) and Restrepo-Echavarría, Rodríguez-Díaz, Castromil (2018). Subsequently, a causal mechanism based on the process tracing method is designed. This enables to reveal the processes that occur just when the cause(s) lead to the observed result. The initial part of the causal mechanism is defined here as the external conditions of the environment, the effect of which on the functioning of political parties is long lasting. These relate to changes in the behaviour of the electorate and their relationship to political parties - de-ideologisation and modernization of society, both reflected in particular in a declining turnout, declining party identification, increasing electoral volatility, and declining interest in political party membership. Consequently, this part defines the nature of the external shock, i.e. whether the environmental conditions in relation to the given political party are manifested in a positive or negative direction (electoral gain or electoral loss). In the event of an electoral loss, we later expect the onset of an internal shock in the form of a change of leader. This assumption is based on strong influence of personalization on today's politics. This is followed by the causal mechanism concerning the party's primary goal, which apparently changes when the party is exposed to an external and/or internal shock. If a party decides to change its primary goal, further internal processes could be expected in the form of organizational changes. We also include "scope 
conditions" in the causal mechanism. These are the variables, which enter it without determining their relationship to the other parts. This means, that they do not necessarily need to be directly linked to them, but we believe that they might have an effect upon the resulting level of professionalization of campaigns. These are the size of the budget, market orientation and party discipline. All parts of the causal mechanism are properly conceptualized in the text presented. Conceptualization is followed by the phase of operationalization, which in the case of process tracing acquires form of a "map of evidence". In other words, we originally propose a specific practical application and method of testing the causal mechanism, including the measurement of the evidence.

\section{PROFESSIONALIZATION OF POLITICAL CAMPAIGNS AND ITS MEASUREMENT}

The process of political professionalization has been an integral part of the research on electoral campaigns and political communication for the last three decades (e.g. Norris, 2000; Mancini, 1999; Denver, Hands, Fisher, MacAllister, 2003; and others). With this umbrella term, the authors attempt to frame all transfigurations of political parties throughout history, regardless of whether these have been instigated by changes in the behaviour of the electorate, the media environment or technological progress. Lilleker and Negrine point out that the concept of professionalization has become a norm in describing the development of political campaigns and communication and, ultimately, a catch-all phrase (Lilleker, Negrine, 2002). With various campaigns developing differently depending on the geographical, temporary and political context, any definition of professionalization aiming at covering all these attributes will unavoidably end up too broad and confusing. This is an example of a phenomenon to which Sartori refers as conceptual stretching (Sartori, 1970).

A clear conceptualization and definition of professionalisation is a prerequisite of operationalisation and measurement. Such definition of the professionalization of electoral campaigns may not be presented unless set within the broader context of the professionalization of politics, itself drawing along two basic lines: the transformations of election campaign and the changes in decision-making as such (Farrell, 1996). Every organisation at any given time needs professionals to survive. At a time when, especially due to external conditions, the mass parties were transformed into electoralprofessional parties, the nature of the experts required for party management 
also changed. While the party bureaucrat was an integral part of the party's hierarchy in the past, with his or her job consisting of administration, one who could hardly find employment outside of politics, the modus operandi of a modern professional in a political party is completely different today. "The professional-electoral party has a weak organisational structure in which the contribution of the traditional bureaucrats is limited relative to that of external professionals endowed with specific technical skills not belonging exclusively to the political sphere. (...) The essence of the party now tends to shift from activists to voters; a large part of its activity revolves around the need to know who the potential voters are in order to reach them and attract their support" (Mancini, 1999, p. 233).

Strömbäck presents a similar definition of professionalization: "professionalization is ultimately about expertise and the use of specialised expertise in campaign-related activities" (Strömbäck, 2007, p. 53). The author thus avoids focusing on specific system variables beyond the reach of the campaign's influence, developing the original minimal definition so that it can be operationalised and enabled for comparative research.

The first researchers to suggest the concept of the operationalisation of campaigns are Gibson and Römmele, introducing in 2009 the additive index that reflected the areas where changes were most evident, so-called CAMPROF index. (Gibson, Römmele, 2009). The indicators are divided into two basic categories: the objectively (e.g. use of direct mail, telemarketing, internal communication system), and the subjectively (use of polls, computer databases, PR consultants) measurable, with the resulting value of the index within the range of 0-30. Jens Strömbäck later modified the original Gibson and Römmele index, drawing on empirical observations of the process of professionalization of Swedish political parties. In contrast to the original method, his modified version of the index does not include the indicator of the existence and parameters of internal communication tools (Strömbäck, 2009). However, the internal communication is proving to be an important element of modern campaigns in both theoretical and empirically verified studies. In addition, it is closely linked to another important indicator, which is the nature of the internal structure of the organisation; the latter was included by Strömbäck in his version of index (modified CAMPROF). Strömbäck adds the indicator of the frequency of working with focus groups and the indicator of the extent and the frequency of reflecting upon the strengths and the weaknesses of the organisation itself. Through such endeavours, the parties can take the necessary steps to shield from/ to prepare for possible attacks from opponents and come up with appropriate 
crisis communication strategies in advance (Strömbäck, 2009). The authors claim that just this element is growing in importance during the time of permanent campaigns and the constantly changing media environment.

Although CAMPROF is no deniable as a reasonable degree of applicability to different types of parties and political systems, may not be perceived the only tool available for measuring professionalism. Tenscher and Mykkänen offer an alternative index that focuses not only on campaign structures (as CAMPROF does) but also on strategies (see Table 1). It attempts to reflect on the nature of changes in the management of campaigns with respect to organisation, but also the strategy. The authors argue that the index, compared to CAMPROF, allows for comparison across countries, time periods and types of elections. The common denominator with the CAMPROF index is the incorporation of both indexes into a model focused on political parties. Tenscher and Mykkännen also agree that the primary actors in the process of the professionalization of campaigns are not changes per se but political parties and their capacity to adapt to internal and external change (Tenscher, Mykkänen, 2014, p. 28). Although the original party-centred model for measuring the professionalization of campaigns was designed for the context of national elections, Tenscher and Mykkänen apply it in their comparative study on both national and second-order elections. The Tenscher - Mykkänen index is additive and two-dimensional, consisting of two sub-indexes: campaign structure and campaign strategy. Based on their own empirical study, the authors prove the validity of such a division. While structures were affected by professionalization in the period under review, strategies were not. The party-centred model also had a lower explanatory power for strategies than for structures.

The authors Restrepo-Echavarría, Rodriguez-Díaz and Castromil in 2018 published the latest theoretical study in the field so far, presenting a completely different way of operationalising the professionalization of campaigns. Although they do not mention at all the Tenscher - Mykkänen method, their index is also two-dimensional: this is, however, where all the similarity ends. The INPROCO $_{\mathrm{T}}$ index, as the researchers call it, consists of organisational (13 indicators) and a communication (14 indicators) dimension. Theoretically, the individual indicators are based on the works by Plasser, Mancini, Römmel and Gibson. The absence of any mention of the Tenscher - Mykkänen method is non-standard and may be a sign of insufficient research on the part of the collective. Logic of this model applied to evaluation of the degree of professionalization is based on the frequencies of individual activities. The variables are not dichotomous but take values 
from 0 (zero or low frequency) to 2 (high frequency) depending on the frequency of occurrence. The trichotomic nature of the indicators amounts to a universal and clear way of operationalisation. Resulting values range from $<0.5$ (low level of professionalism) to $\geq 2$ (high level of professionalism) (Restrepo-Echavarría, Rodríguez-Díaz, Castromil, 2018). A significant advantage of the INPROCO ${ }_{\mathrm{T}}$ index, comparing to all previously published tools, is the inclusion of the latest trends in campaign management. The problem of the index lies, however, with a significant underestimation of the role of volunteers, as the INPROCO $\mathrm{T}_{\mathrm{T}}$ index attributes a higher value to campaigns that fully rely on the work of contractual employees.

Table 1: An Overview of Existing Indexes of Professionalization of Political Campaigns

\begin{tabular}{|c|c|c|c|c|c|}
\hline$\underset{\widetilde{\varpi}}{\check{\varpi}}$ & $\stackrel{㐅}{\stackrel{x}{\Xi}}$ & 染 & 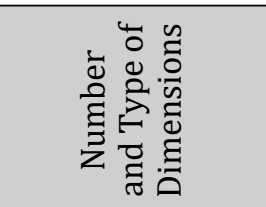 & 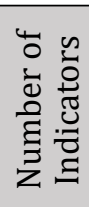 & 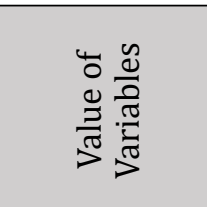 \\
\hline $\begin{array}{l}2001 \\
2009\end{array}$ & $\begin{array}{c}\text { Original } \\
\text { CAMPROF }\end{array}$ & $\begin{array}{l}\text { Gibson and } \\
\text { Römmele }\end{array}$ & $\begin{array}{l}\text { Only Campaign } \\
\text { Structures }\end{array}$ & 10 & $\begin{array}{c}\text { Dichotomous } \\
\text { and } \\
\text { trichotomous }\end{array}$ \\
\hline 2009 & $\begin{array}{l}\text { Modified } \\
\text { CAMPROF }\end{array}$ & Strömbäck & $\begin{array}{l}\text { Only Campaign } \\
\text { Structures }\end{array}$ & 11 & $\begin{array}{c}\text { Mostly } \\
\text { trichotomous }\end{array}$ \\
\hline 2014 & Original & $\begin{array}{l}\text { Tenscher and } \\
\text { Mykkännen }\end{array}$ & $\begin{array}{l}\text { Campaign } \\
\text { Structures and } \\
\text { Strategies }\end{array}$ & 15 & Various \\
\hline 2018 & $\begin{array}{c}\text { Original } \\
\text { INPROCO }_{t}\end{array}$ & $\begin{array}{c}\text { Restrepo- } \\
\text { Echavarría, } \\
\text { Rodriguez-Díaz } \\
\text { and Castromil }\end{array}$ & $\begin{array}{l}\text { Organisational } \\
\text { and } \\
\text { Communicational } \\
\text { Dimensions } \\
\end{array}$ & 27 & $\begin{array}{c}\text { Mostly } \\
\text { dichotomous }\end{array}$ \\
\hline
\end{tabular}

Source: Gibson, Römmele, 2001, 2009; Strömbäck, 2009; Tenscher, Mykkännen, 2014; Restrepo-Echavarría, Rodriguez-Díaz, Castromil, 2018.

\section{CAUSAL MECHANISM OF PROFESSIONALIZATION OF POLITICAL CAMPAIGNS}

The previous chapter briefly summarised the key indexes of campaign's political professionalization published so far. Nevertheless, a comprehensive conceptual framework covering the research made on professionalization of campaigns is still absent. Studies on the professionalization of campaigns over 
the years have identified a number of variables that may play a role. Yet, a causal mechanism that would comprehensively describe the process is still non-existent. Here, a causal mechanism is understood as a complex system that provides conclusions based on the interaction of a number of its parts (Glennan, 1996, p. 52). In social sciences, the main method that allows a study/tracking of the causal mechanisms is the process tracing, more precisely - the theory testing process tracing, a term coined by D. Beach and R. B. Pedersen. It is based on deducing theory from existing literature and subsequent testing of whether the evidence proves the presence of each part of the hypothetical causal chain. This allows us to draw conclusions as to whether the mechanism worked as expected in a given case and whether it was present as a whole. Analogy of the so-called black box can also be used to understand the causal mechanism. A large number of studies evaluating the effect of cause on consequence focus on demonstrating whether the activities have taken place ( $=\mathrm{A})$ and seek to verify (and, if possible, measure the value) the expected outcome $(=\mathrm{B})$. However, they do not disclose anything about why and how A led to B. Thus, the method represents an imaginary black box that remains closed. However, the processtracing opens a metaphorical black box and identifies a causal mechanism inside (Punton, Welle, 2015, p. 3). The defining feature of process tracing is the unpacking of the causal mechanism into individual parts, which are then traced through an in-depth case study. Compared to other methods, the process tracing differs in the types of judgments made and goes beyond the research of correlations between variables: it attempts to trace the theoretical causal mechanisms that connect the variables. It cannot be stated, however, that the assumed mechanism is the only cause behind the result. Nevertheless, the study of causal mechanisms through the process-tracing method allows a researcher to design strong conclusions about causal processes. For this reason, it is a common and invaluable method in social sciences (Beach, Pedersen, 2011).

The present study operates with a comprehensive causal mechanism firmly anchored in current theories on the transformation processes of political parties. Along with the operationalisation of measuring the degree of the professionalization of electoral campaigns, Gibson and Römmele also introduced a causal model of the professionalization of campaigns. It was developed on the assumption that political parties themselves play a major role in the process of the professionalization, a considerably more important role than previously assumed. By way of explanation, when studying the process of professionalization, specific party variables need to be considered, not just the changes taking place at the system level (Gibson, Römmele, 2001) The authors drew on the integrated theory of party change by Harmel and Janda (1994), based on three basic presumptions: 
- Each party has a primary goal;

- The most crucial transformations are instigated exclusively by external shock;

- External shock is an outer stimulus with an impact on the primary goal of the party.

In line with the ideas of Gibson and Römmel, the research presented here acknowledges the goals of a party as one of the conditions that account for the changes within political parties. Furthermore, our research also agrees with Panebianco who describes political parties as inherently conservative institutions that do not change just for the sake of change. Although internal processes are directly responsible for change, they are instigated by external stimuli. The most fundamental changes thus result only from external shock (external stimulus), which effects the party's primary goals and internal processes. The process of professionalization of campaigns has its origins (according to the causal mechanism presented in this study) in profound social changes, which were reflected in de-ideologisation and modernization of society, mirrored then in particular in declining turnout, declining party identification, increasing electoral volatility, and declining interest in political party membership (Rahat, Kenig, 2018, p. 18). These items are collectively referred to in the causal mechanism as environmental factors and their effect on the professionalization of campaigns is longterm. In addition to the mentioned indicators of environmental change, we also include a decrease in support for traditional parties, which is also mentioned in a number of studies (e.g. Bértoa, Rama, 2020). These changes affect the form of the external shock to which the political party in question is exposed. For example, if it is a subject typologically belonging to the traditional parties, strongly affected by the high volatility of their electorate, and conversely by weak party identification, the external shock is likely to be the electoral defeat.

If this pattern of changes to the campaigns is applied, according to Harrop, new marketing techniques are most often adopted after severe electoral defeats, that is as a result of a strong external shock (Harrop, 1990). Gibson and Römmel came up with the hypothesis that new techniques are more likely to be adopted in the campaigns of parties with the primary goal of maximising the votes. In addition, they defined three organisational features of a party that affect the degree of professionalization. They were resources, internal structure, and ideology. According to the authors, parties with larger resources will be able to apply a full range of tools associated 
with the marketing approach. Entities with a clearly defined party hierarchy find it easier to implement the extensive structural and cultural changes required by professionalization. Finally yet importantly, right-wing parties are more likely to follow marketing principles and hire external agencies, as these are the actions completely consistent with their ideology. The last presupposition is also mentioned by Kavanagh (1996), Scammell (1995) and Lisi (2013). In contrast, an empirical research conducted on German and Swedish parties did not support the hypothesis. (Strömbäck, 2009) For this reason, the present study does not consider the role of ideology in the professionalization of campaigns.

The very premise that parties following marketing principles are more likely to be more professional in preparing and running a campaign appears logical. However, marketing principles are not necessarily linked only to right-wing parties. Therefore, instead of the condition of ideology, we originally propose to include the scope condition of market orientation of the party as defined by Lees - Marshment (2001). Moreover, campaign research has been conducted through the marketing framework since the 1970s, but Farrell and Bowler later, in their 1992 study Electoral Strategies and Policital Marketing, acknowledge the limits of the purely marketing concept of campaign professionalization. In their view, "marketing models can be a tool to describe a particular type of activity, but it is not clear that they would help us understand ongoing processes or provide a theoretical framework for evaluating campaigns." (Bowler,Farrell, 1992). That is a reason for including market orientation into scope conditions in our research. Remaining organizational feature defined by Gibson and Römmel "extensive budget" was also included into scope conditions alongside with the party discipline as a factor which, in addition to the formal setting of the organizational structure, can contribute to the degree of professionalization. Only if all levels of the party and their actors understand the goals of the campaign and respect these goals and guidelines, we can speak of a professionally led organization (campaign).

Given the fact that since the 1960s and even earlier, politics has been strongly affected by the expansion of the mass media, the role of personalities is gaining in importance: in the event of an external shock in the form of an electoral defeat, the internal reaction of the party will probably be the change on the dominant fraction leader. External shock in any form, including such a change in party leadership, eventually affects the party's primary goal. If a party wins a larger share of seats than in the previous election, for example, its primary goal is likely to maintain the growing trend in the upcoming 
elections. In response to the change in the primary goal, changes in the organisational structure of the party are extremely likely. These changes can manifest themselves at various levels, whether in greater centralisation and streamlining of decision-making processes or the creation and development of the party's professional background.

Scheme 1: Proposal of Causal Mechanism of the Professionalization of Electoral Campaigns

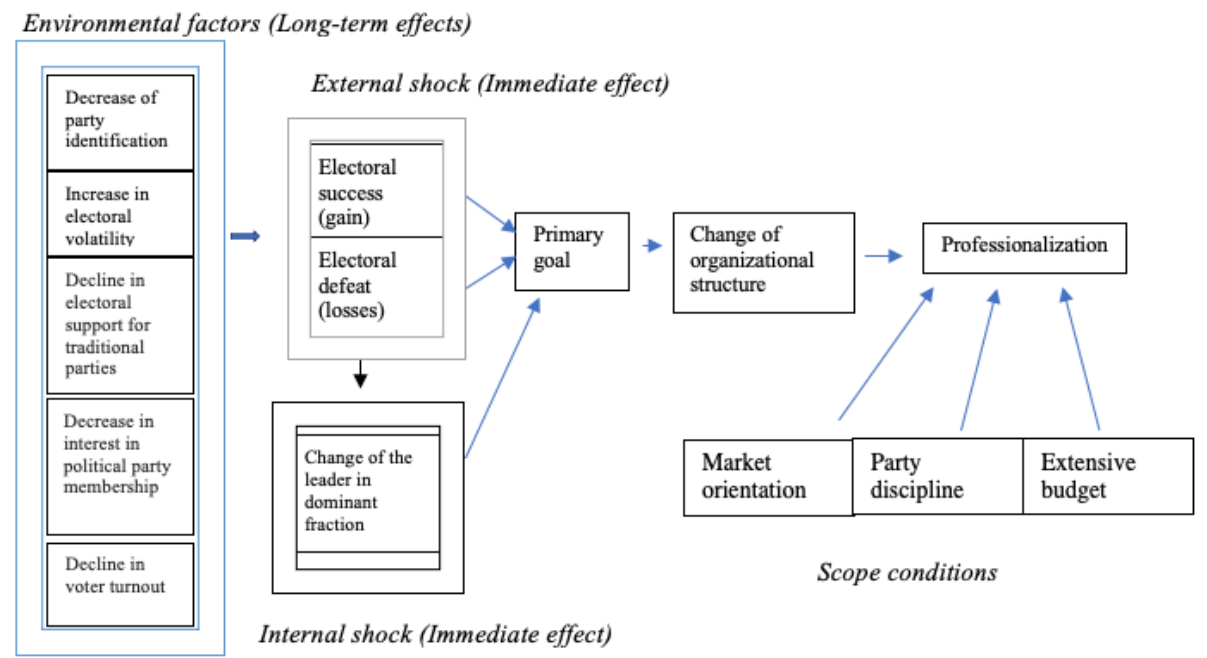

Source: Author

One of the positive attributes of this causal mechanism is its applicability for research of the professionalization of electoral campaigns in various types of political systems. However, since it is based on the theories of authors who focused mainly on the realities of Western European democracies or the USA, it is necessary to be extraordinary scrupulous when applying it to the cases as the post-communist countries. For example, environmental factors may enter into the mechanism more significantly in developed countries with uninterrupted democratic experience than in the post-communist countries. Nevertheless, they are also already manifested in these states (see more Fagan, Kopecký 2018; Linek, Pecháček 2005). The causal mechanism can also be verified in the countries with different electoral systems. Although political parties are likely to have different primary objectives in majority or proportional systems, the causal mechanism does not define their form. 
We are interested in how the primary goal could have changed depending on the external and, eventually, also internal shock. A similar argument can be applied for a change identified in organizational structure. Political parties in Europe usually are more rigid in their organizational structure than comparing, for example, to the US parties. Again, however, in the causal mechanism, a predetermined idea of organizational structure is not applied here, but this article is rather to examine how it has changed as a result of processes.

\subsection{Operationalization of the Evidence}

If using the process tracing method, after the initial phase of conceptualization the phase of operationalization occurs, and then it is necessary to clearly determine the type of evidence, because when present in the case, it indicates the presence of the presumed causal mechanism. "If we can claim that the actual evidence found or not found for each of the parts of the mechanism matched what our propositions about evidence were, and we can trust it, we can then infer that the hypothesized causal mechanism is present in the case on the basis of Bayesian logic" (Beach, Pedersen 2016,p. 324).

\subsubsection{Environmental Factors}

Research on party identification has its origins in the 1950s due to the work of Argus Campbell, who, with his colleagues, looked for variables that influenced the formation of opinions and decisions of voters during elections. At that time, the research team found that people often voted because of their long-established family traditions as well as the based on the decisions they had made in previous elections. The information is based on the theory of social identity, which likens these party ties to the socio-economic ties. However, a different finding from Campbell's research is essential for the operationalization of party identification. He managed to prove a significant difference in the connection to the party and the electoral preference. This means that people with a certain party ties (or identification) can vote for candidates from different political parties. This conceptual independence brings additional meaning to the party identification, and every election survey today includes some form of inquiry into the party identification (Dalton, 2016). For example, for comparative studies, it is possible to choose the form of questioning from the Comparative Study of Electoral Systems (CSES) model to measure the degree of party identification. 
Another environmental factor that affects the functioning of political parties is the increase in electoral volatility, i.e. an aggregate indicator of the consistency and stability of electoral behaviour. In order to measure volatility at the aggregate level, the Pedersen index is applied. However, Peter Mair is of the opinion that this aggregate calculation may strongly underestimate the true level of vote transfer (Mair, 2013). On the one hand, there is a volatility, which occurs when voters move between the existing parties, and this type of volatility does not necessarily lead to significant instability of the political system (within system volatility). On the other hand, there is a volatility caused by the new parties entering into the system or, conversely, by the old parties disappearing from the system. Volatility of this kind may cause an increased instability (extra system volatility) (Mainwaring, Gervasoni, España-Najera, 2017). Therefore, in addition to the Pedersen index, we originally recommend measuring the level of in- system and extra- system volatility as well.

The third set of environmental factors is the decline in electoral support for traditional parties. However, from the very beginning there is a problem with the very definition of a traditional party. There is no clear definition of the term in the literature. One option is to determine the type of party (traditional vs. new) based on its age. The method in question is, however, quite problematic, because in the many party systems there are parties tracked back to the $19^{\text {th }}$ century, but also parties that emerged in $21^{\text {st }}$ century - in both cases these subjects (themselves) identify as traditional. I believe then, a more appropriate way is to define a traditional party according to its ideological and program positions. For new political parties (e.g. cyber parties, populists) they may manifest a significant departure from traditional political ideologies reflected in their rejection of the politics based on the right-left cleavages.

The decline in interest in membership in political parties is another strong manifestation of the stronger alienation of the public from political parties. Decades ago, they could still rely on mass membership, which formed the basis of their legitimacy. In addition, members provided their political parties with much-needed financial and human resources (Rahat, Kenig, 2018, p. 19). Transformation of the character of the parties reflected on their need to strive for a more mass membership base. "As the parties began to appeal to the electorate as a whole, instead of trying to represent a specific class or social group, their strategies became increasingly aggressive. Their goal was simply to persuade voters rather than mobilize party members" (Biezen van, Poguntke, 2014, p. 205). The focus was on the total set of voters, not the loyal followers. However, this pushed on the political parties 
even more at risk of voter volatility. The operationalization of the degree of partisanship is relatively simple and expressed by the reported numbers of members of parliamentary political parties. In the case of a comparative study, the essential information is whether there has been a decrease or an increase in the membership.

The last environmental factor mentioned in the causal mechanism of professionalization of campaigns is the decline in voter turnout. "Although the voter population is growing globally, as is the number of countries in which elections take place, the global average turnout has fallen sharply since the 1990s" (Solijonov, 2016, p. 24). The variables that affect citizens' willingness to vote are economic, political as well as institutional in nature. However, especially for the purposes of the present study, one specific factor is relatively crucial. It is the ability or inability of political parties and candidates to mobilize their constituents through electoral campaigns. According to recent studies (e.g. Gerber, Green, 2000 or Goldstein, Ridout, 2002), the decline in turnout can be explained by the lower efficiency of political mobilization. The character and quality of contacts have a specific influence. Especially in the days of mass parties, which were firmly entrenched in the social structure of society, the leading ambassadors of the party were its members, who naturally addressed their family members, acquaintances and neighbours. With the expansion of marketing thinking and methods (e.g. phone banking and hostesses or another type of trained externally hired employee), whose work on voters has a completely different character, began. However, the relationship between electoral campaigns and turnout is of a two-way character, essentially cyclical. Lower voter mobilization efficiency may lead to lower turnout, which again forces political parties to invest more in the professionalization of the election campaign with a view to better election results.

\subsubsection{Internal and External Shocks}

The operationalisation of external and internal shocks is likewise relatively clear. When the party in question loses against the previous elections, such party can speak of an electoral defeat and vice versa. The only problematic aspect is defining the type of reference elections: specifically, the results of which elections are to be compared. Should there be two consecutive elections of different orders or elections of the same significance? The present study chooses the first of the two possible paths. Although the degree of professionalization of campaigns is likely to vary across elections 
of a different order (first-order/ second-order elections), the result of any election may be the trigger for change. At a time, for example, when a party is losing both local and European elections (both perceived as second-order elections), it will most likely not wait for the outcome of parliamentary elections and thus put itself at risk of copying the malevolent trend of the previous elections.

\subsubsection{Primary goal and Organisational Structure}

A more complicated issue arises when it comes to evaluating the changes in the primary goal. At first, political parties are rarely open towards the public about their genuine goals. They often make, however, public proclamations about their intentions to become a new leading force in the political market or, for example, a new leader of the opposition. The evaluation of this part of the causal mechanism is to largely rely on the researcher's original judgment based on a wide range of available data (public appearances of party representatives, internal documents, interviews with leaders, etc.) A similar degree of subjectivity is required to evaluate changes in the organisational structure: these, in their turn, should be manifested in a greater emphasis on clarifying individual roles within a party, streamlining decision-making mechanisms and centralisation.

\subsubsection{Scope conditions}

While the already mentioned concept of the market-oriented party (developed according to the Lees-Marshment model) can be used to operationalize market orientation (see Lees-Marhsment, 2001), measuring the degree of internal party discipline is again influenced by the researcher's subjective assessment based on available data (e.g. internal party documents, statutes, interviews with party representatives at all levels). On the contrary, valuing an extensive budget is relatively easy and can be achieved by comparing budgets of the same party in the successive elections. However, with regard to the practice of political parties, it is appropriate to compare elections of the same nature, as parties usually invest more in first-order elections.

The following argument road map (as used e.g. by Beach and Pedersenem, 2016) describes both the form of the presumed causal relationship, the level of trust in it, but also the form of evidence that supports or refutes the original assumptions. 
Table 2: Argument Road Map Presented In This Study

\begin{tabular}{|c|c|}
\hline Causal relationship & $\begin{array}{c}\text { Conditions of the environment lead to external } \\
\text { and internal shocks, and these ultimately } \\
\text { through organizational changes lead to the } \\
\text { professionalization of campaigns }\end{array}$ \\
\hline $\begin{array}{c}\text { Degree of confidence in the } \\
\text { causal mechanism }\end{array}$ & $\begin{array}{c}\text { A low - existing research focuses primarily } \\
\text { on outputs and partly on causes of } \\
\text { professionalization. However, has not defined a } \\
\text { mechanism between them. }\end{array}$ \\
\hline Assumptions & Type of evidence \\
\hline $\begin{array}{c}\text { Declining party } \\
\text { identification }\end{array}$ & Surveys (e.g. CSES) \\
\hline $\begin{array}{c}\text { Increase in electoral } \\
\text { volatility }\end{array}$ & The Pedersen index, within system and extra \\
system volatility
\end{tabular}

Source: Author 


\section{CONCLUSION}

The aim of the article was to introduce a proposal for a conceptual framework for research into the professionalization of electoral campaigns. This article responds to the absence of a deeper knowledge of the factors that lead to relatively complex processes within political parties, the result of which is the professionalization of electoral campaigns. The conceptual framework is presented in the form of causal mechanism, which helps answering in some detail the question of what happens at the moment when the considered individual variables interact with each other.

Comprehensive causal mechanism is firmly anchored in the current theories on the transformation processes of political parties, specifically the integrated theory of party change as defined by Harmel and Janda (1994). This theory is based on three presumptions. Firstly, each political party has a primary goal. Secondly, the most crucial transformations are instigated exclusively by external shock, and finally, external shock is an outer stimulus with an impact on the primary goal of the party. Gibson and Römmel (2009) further apply the integrated theory of party change to the professionalization of campaigns and come up with a hypothesis that assumes a higher probability of adopting new techniques in campaigns for parties whose primary goal is to maximize their votes. In addition, they define three organizational features of the parties that affect the degree of professionalization - resources, internal structure, and ideology. However, as we argue in the text, so far there has been a lack of understanding of what party processes take place in the interaction of external and internal shocks and what specific forms these shocks may take. According to our hypothetic causal mechanism, the process of professionalization of campaigns has its origins in social changes, which are reflected in particular in declining voter turnout, declining party identification, increasing electoral volatility, and decrease in support for traditional parties and declining interest in political party membership. In the causal mechanism these items are collectively referred to as environmental factors, which, according to the assumption originally presented herein, may lead to an external shock in the form of electoral loss or gain.

While both types of external shock subsequently affect the form of the party's primary goal (e.g. in the case of electoral gains, the current opposition party focuses on successfully managing its government role), only in electoral defeat does the causal mechanism assume internal shock. It takes the form of changes of the leader in the dominant faction within the party, or the whole party. This assumption is based on the reality of personalization of politics and campaigns, where it is the party leader who is responsible not only for the electoral campaign, 
but also bears political responsibility for the electoral successes or failures of the party. When a party changes its primary goal, dependent organizational changes can be expected. For example, if a party is gaining in popularity and external shocks are of electoral gains or an increase in electoral preferences, then a political entity can be expected to invest in developing its team of experts in preparation for taking over the government positions. It is also possible that the management will try to centralize decision-making processes so that the party as a whole will appear before the voters in a unified and actionable way. Organizational changes, such as the mentioned centralization or hiring of external professionals, are de facto signs of efforts to further professionalization of a given political party functioning, especially its campaign. The causal mechanism also contains so called scope conditions that can contribute to the level of professionalization of campaigns. In contrast to previously published texts by Gibson and Römmele (2009) or Tenscher and Mykkänen (2014), which attributed a significant influence to the volume of funds invested in the organization of the campaign and its ideology, this article considers the level of its internal party discipline to be important factor as well. A formal organizational setting alone is not enough for a higher degree of professionalization. Therefore, it is essential in each case that we examine to document empirically the state of party discipline through individual evidence. For the evidentiary process, this article introduces the author's original "argument road map", in which both concrete and operationalized assumptions are defined altogether with the type of evidence any researcher should look for.

Unlike Gibson and Römmele or Tenscher and Mykkänen, the author of this article does not assume the influence of ideology on professionalization. The change in the environmental conditions in which the parties operate today, and those defined above, affects political parties and their tendency to professionalize, regardless of their ideology. However, what can positively affect the degree of professionalization of campaigns is the party's approach to the application of marketing principles. In other words, whether the party is market-oriented, as defined by Lees-Marshment (2001).

In conclusion, it is worth mentioning that, becasue the existing research focuses primarily on outputs and partly on causes of professionalization and has not defined a mechanism between them, the initial level of confidence in the validity of the proposed causal mechanism is intentionally set low. The level of confidence, however, can be increased by future comparative studies, in which researchers will be able to gather quality evidence supporting or, conversely, refuting individual parts of the causal mechanism. Based on them, the causal mechanism can then be modified to correspond to the empirical results. 


\section{REFERENCES}

BEACH, D., PEDERSEN, R. B. (2011). What is Process-Tracing Actually Tracing? The Three Variants of Process Tracing Methods and Their Uses and Limitations. In: APSA 2011 Annual Meeting. [online], 35 pp. Available at: https://papers.ssrn.com/sol3/papers.cfm?abstract_ id=1902082\#references-widget [Accessed 18.4.2021]

BEACH, D., PEDERSEN, R. B. (2016). Causal Case Study Methods: Foundations and Guidelines For Comparing, Matching, and Tracing. University of Michigan Press, 2016. 398 pp. DOI: https://doi.org/10.3998/ mpub.6576809

BÉRTOA, F. C., RAMA, J. (2020). Party decline or social transformation? Economic, institutional and sociological change and the rise of antipolitical-establishment parties in Western Europe. In: European Political Science Review. Vol. 12, No. 4, 2020. pp. 503-523. DOI: https://doi. org/10.1017/S1755773920000260.

BIEZEN VAN, I., POGUNTKE, T. (2014). The decline of membership-based politics. In: Party Politics. Vol. 20, No. 2, 2014. pp. 205-216. DOI: https:// doi.org/10.1177/1354068813519969.

BLATTER, J., HAVERLAND, M. (2014) Case Studies and (Causal-) Process Tracing. In: ENGELI, I., ALLISON, C.R. (eds) Comparative Policy Studies. Research Methods Series. Palgrave Macmillan, London, 2014. DOI: https:// doi.org/10.1057/9781137314154_4.

BOWLER, S., FARRELL, D.M. (1992). Electoral Strategies and Political Marketing. Palgrave Macmillan UK, 1992. 245 pp. DOI: https://doi. org/10.1007/978-1-349-22411-1.

DALTON, R. 2016. Party Identification and Its Implications. In. Oxford Research Encyclopedia of Politics. [online]. Available at: https:// oxfordre.com/view/10.1093/acrefore/9780190228637.001.0001/ acrefore-9780190228637-e-72. DOI: https://doi.org/10.1093/ acrefore/9780190228637.013.72.

DENVER, D., HANDS, G., FISHER, J., MACALLISTER, I. (2003). Constituency Campaigning in Britain 1992-2001: Centralization and Modernization. In: Party Politics. Vol. 9, No. 5, 2003. pp. 541-559. DOI: https://doi. org/10.1177/13540688030095002.

FAGAN, A., KOPECKÝ, P. (2018). The Routledge Handbook of East European Politics. Routledge, 2018. 370 pp. DOI: https://doi. org/10.4324/9781315687681. 
FARRELL, D. (1996). Campaign Strategies and Tactics. In: LEDUC, L., NIEMI, R. G., NORRIS, P. (eds) Comparing Democracies. Elections and Voting in Global Perspective. Sage Publication, 1996. 440 pp.

GIBSON, R., K., RÖMMELE, A. (2001). Changing Campaign Communications: A Party-Centered Theory of Professionalized Campaigning. In: The Harvard International Journal of Press/Politics, Vol. 6, No. 4, 2001. pp. 3143. DOI: https://doi.org/10.1177/108118001129172323.

GERBER, A. S., GREEN, D. P. (2000). The Effects of Canvassing, Telephone Calls, and Direct Mail on Voter Turnout: A Field Experiment. In: American Political Science Review. Vol. 94, No. 3, 2000. pp. 653 - 663. DOI: https:// doi.org/10.2307/2585837.

GIBSON, R., K., RÖMMELE, A. (2009). Measuring the professionalization of political campaigning. In: Party Politics. Vol. 15, 2009. pp. 265-293. DOI: https://doi.org/10.1177/1354068809102245.

GLENNAN, S. (1996). Mechanisms and the nature of causation. In: Erkenntnis. Vol. 44, No. 1, 1996. pp. 49-71. DOI: https://doi.org/10.1007/ BF00172853.

GOLDSTEIN, K. M., RIDOUT, T. N. (2002). The politics of participation: Mobilization and turnout over time. In: Political Behavior. Vol. 24, No.1, 2002. pp. 3-29. DOI: https://doi.org/10.1023/A:1020930604938.

HARMEL, R., JANDA, K. (1994) An Integrated Theory of Party Goals and Party Change. In: Journal of Theoretical Politics. Vol. 6, No. 3, 1994. pp. 259-87. DOI: https://doi.org/10.1177/0951692894006003001.

HARROP, M. (1990). Political Marketing. In: Parliamentary Affairs. Vol. 43, No. 3, 1990. pp. 277-291.

LINEK, L., PECHÁČEK, Š. (2005). K důvodům nízkého počtu členů českých politických stran. In: MANSFELDOVÁ, Z., KROUPA, A. (eds.) Participace a zájmové organizace v České republice. Praha: Sociologické nakladatelství SLON, 2005. 244 pp.

LISI, M. (2013). The Professionalization of Campaigns in Recent Democracies: The Portuguese Case. In: European Journal ofCommunication.Vol.28, No.3, 2013. pp. 259-276. DOI: https://doi.org/10.1177/0267323113475463. KAVANAGH, D. (1996). New Campaign Communications: Consequences for British Political parties. In: Harvard International Journal of Press/ Politics. Vol. 1, No. 3, 1996. pp. 60-76. DOI: https://doi.org/10.1177/108 $1180 \times 96001003006$. 
LEES-MARSHMENT, J. (2001). The product, sales and market-oriented party - How Labour learnt to market the product, not just the presentation. In: European Journal of Marketing. Vol. 35, No. 9-10, 2001. pp. 1074-1084. DOI: https://doi.org/10.1108/EUM0000000005959.

LILLEKER, D. G., NEGRINE, R. (2002) Professionalization: Of What? Since When? By Whom?" In: Harvard International Journal of Press/Politics. Vol. 7, No. 4, 2002. pp. 98-103. DOI: https://doi. org/10.1177/108118002236354.

MAIR, P. (2013). Ruling the Void: the Hollowing of Western Democracy. Verso, 2013. $160 \mathrm{pp}$.

MAINWARING, S., GERVASONI, C., ESPAÑA-NAJERA, A. (2017). Extra- and within-system electoral volatility. In: Party Politics. Vol. 23, No. 6, 2017. pp. 623-635. DOI: https://doi.org/10.1177/1354068815625229.

MANCINI, P. (1999). New Frontiers in Political Professionalism. In: Political Communication. Vol. 16, 1999. pp. 231-245. DOI: https://doi. org/10.1080/105846099198604.

NORRIS, P. (2000). A Virtuous Circle: Political Communications in Postindustrial Societies. Cambridge University Press, 2000. 420 pp. DOI: https://doi.org/10.1017/CB09780511609343.

PUNTON, M., WELLE, K. (2015). Straws-in-the-wind, Hoops and Smoking Guns: What can Process Tracing Offer to Impact Evaluation? In: CDI Practice Paper 10. Brighton: IDS.

RAHAT, G., KENIG, O. (2018). From Party Politics to Personalized Politics? Party Change and Political Personalization in Democracies. Oxford University Press, 2018. 400 pp. DOI: https://doi.org/10.1093/ oso/9780198808008.001.0001.

RESTREPO-ECHAVARRÍA, N. J., RODRÍGUEZ-DÍAZ, R., CASTROMIL, A. R. (2018). Proposal of an indicator to measure the professionalization of election campaigns: The case of Colombia. In: Profesional de la Informacion, Vol. 27, No. 2, 2018. pp. 289-299. DOI: https://doi. org/10.3145/epi.2018.mar.07.

SARTORI, G. (1970). Concept Misformation in Comparative Politics. In: American Political Science Review. Vol.64, No. 4, 1970. pp. 1033-1053. DOI: https://doi.org/10.2307/1958356.

SCAMMEL, M. (1995). Designer Politics. How Elections Are Won. Palgrave Macmillan, 2005. 342 pp. DOI: https://doi.org/10.1007/978-1-34923942-9.

SOLIJONOV, A. (2016). Voter Turnout Trends around the World. IDEA, 2016. 54 pp. DOI: https://doi.org/10.1002/rwm3.20358. 
STRÖMBÄCK, J. (2007). Political Marketing and Professionalized Campaigning. In: Journal of Political Marketing. Vol. 6, No. 2-3, 2007. pp.49-67. DOI: https://doi.org/10.1300/J199v06n02_04.

STRÖMBÄCK, J. (2009). Selective Professionalisation of Political Campaigning: A Test of the Party-Centred Theory of Professionalised Campaigning in the Context of the 2006 Swedish Election. In: Political Studies. Vol. 57, 2009. pp. 95-116. DOI: https://doi.org/10.1111/j.14679248.2008.00727.x.

TENSCHER, J., MYKKÄNEN, J. (2014). Two Levels of Campaigning: An Empirical Test of the Party-Centred Theory of Professionalisation. In: Political Studies. Vol. 62, 2014. pp. 20-41. DOI: https://doi. org/10.1111/1467-9248.12104. 